\title{
Effect of ploidy on the mortality of Crassostrea gigas spat caused by OsHV-1 in France using unselected and selected OsHV-1 resistant oysters
}

\author{
Lionel Dégremont ${ }^{1}$, Christophe Ledu ${ }^{1}$, Elise Maurouard ${ }^{1}$, Max Nourry $^{2}$ and \\ Abdellah Benabdelmouna ${ }^{1}$ \\ *: Corresponding author : Lionel Dégremont, email address : lionel.degremont@lfremer.fr
}

${ }^{1}$ SG2M, LGPMM, Ifremer, La Tremblade, France

${ }^{2}$ SG2M, LSPC, Ifremer, La Tremblade, France

\begin{abstract}
:
The effect of ploidy on the mortality of Crassostrea gigas spat caused by the ostreid herpesvirus (OsHV-1) genotype $\mu \mathrm{Var}$ was investigated at five sites along the Atlantic coast in France in 2011. Sibling diploids and triploids were produced using either unselected or selected OsHV-1-resistant oysters. No significant interactions were found between the factors of environment, genotype and ploidy at the endpoint dates. The mean mortality rates at the sites were 62 and $59 \%$ for diploids and triploids, respectively, and the two rates were not significantly different. The mean mortality rates were 33 and $32 \%$ for sibling diploids and triploids, respectively, when OsHV-1-resistant parents were used, and 91 and $85 \%$, respectively, when unselected parents were used. The results were confirmed through other broodstocks tested in 2013. Our study is the first to clearly show that mortality related to OsHV-1 is similar between diploids and triploids in C. gigas when the same germplasm is used for both ploidy. Furthermore, OsHV-1 resistance was not substantially altered by triploidization, indicating that the achieved selective breeding of diploid oysters for OsHV-1 resistance can be translated into improved survival in triploids.
\end{abstract}

Keywords: Diploid ; Triploid ; Mortality ; Crassostrea gigas ; Ostreid herpesvirus OsHV-1 
Massive mortality primarily affecting spat has afflicted C. gigas in France since 2008 and is largely attributable to the ostreid herpesvirus OsHV-1 $\mu$ Var (Segarra, Pépin, Arzul, Morga, Faury \& Renault 2010; Dégremont 2011; Pernet, Barret, Le Gall, Corporeau, Dégremont, Lagarde, Pépin \& Keck 2012). Similar mortality has also been reported in other European countries, Australia, New Zealand and on the western coast of the USA during this same time period (EFSA 2010; Cameron \& Crane 2011; Burge \& Friedman 2012; Lynch, Carlsson, Reilly, Cotter \& Culloty 2012; Martenot, Fourour, Oden, Jouaux, Travaille, Malas \& Houssin 2012; Peeler, Allan Reese, Cheslett, Geoghegan, Power \& Thrush 2012; Roque, Carrasco, Andree, Lacuesta, Elandaloussi, Gairin, Rodgers \& Furones 2012; Jenkins, Hick, Gabor, Spiers, Fell, Gu, Read, Go, Dove, O'Connor, Kirkland \& Frances 2013; Paul-Pont, Dhand \& Whittington 2013). Since the first investigations of OsHV-1-related mortality, both wild-caught and hatchery-produced seed as well as both diploids and triploids have been affected, with mortality rates usually exceeding 80\% (EFSA 2010; Pernet et al. 2012; Jenkins et al. 2013). Meanwhile, breeding investigations have revealed a high genetic basis for survival during summer mortality events in juvenile C. gigas (Dégremont, Ernande, Bedier \& Boudry 2007; Dégremont, Bédier \& Boudry 2010a). It was also recently shown that selected oysters resistant to the summer mortality events were resistant to OsHV-1 in the context of the more severe mortality outbreaks in France since 2008 (Dégremont 2011).

The French oyster production of Crassostrea gigas is based on two types of spat, wild-

57 caught and hatchery-produced, with the percentages of each type varying each year. The 
amount of wild-caught spat strongly depends (1) on diseases, as larvae are highly susceptible to OsHV-1 (Le Deuff, Nicolas, Renault \& Cochennec 1994) and they develop in environmental condition that favor the disease (seawater temperature higher than $16^{\circ} \mathrm{C}$ ), (2) on environmental conditions (seawater temperature, food, pollutants...), and (3) the number of collectors. Since 2008, French oyster farmers have increased their spat collection capacity tremendously in response to the severe mortality devastating $C$. gigas oysters less than a year old. During the same time period, the amount of hatcheryproduced spat increased regularly each year, reaching approximately three billion units in 2012, primarily in the production of triploids. In France, all triploids are produced by private hatcheries, crossing diploid females from their own stocks, with tetraploid males from a unique stock produced and maintained at the Ifremer hatchery in La Tremblade. Generally, each commercial spawn requires one to ten tetraploid males for the production of all-triploid offspring.

Although a significant portion of French oyster production is based on triploids, the effect of ploidy has not been investigated in any of the studies on OsHV-1-related mortality. The aim of the present study was to evaluate the effect of ploidy on OsHV-1related mortality in C. gigas seed. To avoid confounding ploidy with the batch effect, triploids and diploids originating from the same genetic background were used using either unselected or OsHV-1-resistant oysters, thereby permitting the assessment of whether selective breeding can be transferred to polyploids.

\section{Materials and Methods}




\section{Oyster broodstocks}

82 All broodstocks used in this study were sampled in the Marennes-Oléron Bay. This site contributes in average each year to $50 \%$ of the amount of the wild-caught oysters in

France. Also, numerous mortality outbreaks related to OsHV-1 are reported in the Marennes-Oléron Bay since at least 1998, the $\mu$ Var genotype being systematically detected every year since 2008 (Segarra et al. 2010; Garcia, Thebault, Dégremont, Arzul, Miossec, Robert, Chollet, Francois, Joly, Ferrand, Kerdudou \& Renault 2011). Further details on mortality occurrence related to the referent genotype OsHV-1 are given in Garcia et al. (2011). More recently, Dégremont (2013) showed that mortality related to OsHV-1 $\mu$ Var between 2009 to 2012 occurred when seawater temperature was higher than $16^{\circ} \mathrm{C}$, and commonly reached $80 \%$ for unselected juvenile oysters.

Five broodstocks were used in this study, three for experiment 1 in 2011 (Fig. 1) and two for experiment 2 in 2013. For experiment 1, the first broodstock was the seventh generation of a bi-parental family produced and selected during the MOREST program in 2001, which aimed to study the summer mortality phenomenon of C. gigas in France (Samain \& McCombie 2008). The selection criterion was for a higher survival rate during summer mortality events for oysters lesser than one year old (Dégremont et al. 2010a). This family was then reproduced over six generations from 2002 to 2010, using around 30 parents per generation. Lately, the family was subsequently found to have higher resistance to OsHV-1 $\mu \mathrm{Var}$ in the context of the massive mortality occurring in France since 2008 (Dégremont 2011). The second broodstock, a wild stock sampled from Marennes-Oléron Bay in 2010, was used to produce the controls. As all controls produced since 2009 exhibits similar but high mortality (>80\%) related to OsHV-1, we assumed that our controls should be considered as representative of the wild stocks in 
France. The last broodstock was a tetraploid stock produced and maintained in our quarantine facility at the Ifremer experimental hatchery in La Tremblade, with all effluents treated to prevent its dissemination in the wild. The tetraploid stock is the 5th generation of reproduction of tetraploid oysters, which were directly induced from diploid animals as described in the patent FR2913982A1 (Benabdelmouna \& Ledu 2007). This tetraploid stock is the one used by all French commercial hatcheries starting from 2010. The last two broodstocks described above are both considered unselected oyster stocks in terms of OsHV-1-related mortality occurring in France since 2008.

For experiment 2, two broodstocks were sampled in the wild in the Marennes-Oléron Bay at two different sites in 2008, and were then reproduced in 2009 in our hatchery. For each broodstock, mass selection on survival in the field in the context of mortality outbreaks related to OsHV-1 at the spat stage was achieved over three generations with the production of one generation per year, starting in 2010, along with their respective control, i.e. oysters protected from the mortality risk factors, and spawned simultaneously with their selected counterparts each year.

\section{Hatchery and nursery}

For experiment 1, oysters were stripped-spawned on 8 February 2011, after conditioning the broodstocks at the Ifremer hatchery in La Tremblade. For the selected family, the eggs of 23 females were collected and divided into two pools. The first pool was fertilized with the spermatozoa from seven males, without controlling the contribution of the parents, producing the batch named $2 \mathrm{nR}$ (with $\mathrm{R}$ indicating resistance to OsHV-1-related mortality). The second pool was used for the production 
of triploids, which were chemically induced using cytochalasin B (CB, Sigma C6762) to block the second polar body (PB2) according to a protocol modified from Gérard, Ledu, Phelipot \& Naciri-Graven (1999). The gametes and embryos were first concentrated in $1 \mathrm{~L}$ of $1 \mu \mathrm{m}$ filtered sea water (FSW) in beakers at $25^{\circ} \mathrm{C}$. CB was dissolved in dimethyl sulfoxide (DMSO) and used at a final concentration of $0.5 \mathrm{mg} \mathrm{L}^{-1}$. At $20 \mathrm{~min}$ postfertilization (PF), the oyster embryos were incubated with CB for 15 min to suppress the expulsion of PB2. After the treatment period, the embryos were thoroughly washed to remove CB by filtering the embryos through a $10 \mu \mathrm{m}$ sieve, followed by rinsing in DMSO in FSW $\left(1 \mathrm{ml} \mathrm{L}^{-1}\right)$ for at least $15 \mathrm{~min}$. The progeny obtained was designated 3nR (Fig. 1). Similarly, two batches, 2nC and 3nC (C indicating control), were produced from the wild stock using 20 females and nine males. Finally, the eggs from the selected family and the wild stock were both fertilized with sperm from seven tetraploid males to produce all-triploid batches respectively named 3nA and 3nB (Fig. 1).

At 50 min PF, the larvae were transferred to 150 -L fiberglass tanks containing FSW at $22-24^{\circ} \mathrm{C}$, and grown for $24 \mathrm{~h}$ at a density of 100 larvae $\mathrm{mL}^{-1}$ and then at a density of 5 larvae $-\mathrm{mL}^{-1}$. The water in the tanks was changed every two days. Starting at 24 hours PF, the larvae were fed a mixed diet of Isochrisis galbana, Chaetoceros gracilis and Tetraselmis sueccica daily at a rate of 20 cells $\mu^{-1}$ per day for each algal species. For the CB-treated larvae, the larvae were subdivided into different size classes at each water change. The DNA ploidy level of each size class was verified using flow cytometry (FCM) from a sample of larvae to identify the classes with the highest percentage of triploid larvae. Similarly, spat originated from CB-treated batches were periodically sorted by size, and the DNA ploidy level of individual spat from each size class was also verified by FCM to determine the size class with the highest percentage 
152 of triploids. Thereafter, only the size classes with the highest percentages of triploids from a sample of 100 spat were maintained and used for the laboratory and field studies.

154 The six batches were grown using the standard conditions applied in the hatchery and subsequently maintained in our hatchery or transferred to the Ifremer nursery in Bouin. During all steps of the production cycle, the batches were observed for any signs of abnormal mortality.

For experiment 2, oysters were stripped-spawned on 6 March 2013. Similar protocol was performed by producing one batch of diploid control $(2 \mathrm{nC})$, one batch of diploid selected oysters (2nR) and one batch of CB-induced triploid selected oysters (3nR) per broodstock. For each cross, 11 to 27 parents were used.

\section{Laboratory and field study}

For experiment 1 , the six batches produced were tested in the laboratory for a cohabitation trial at the Ifremer hatchery in La Tremblade, which is located within Marennes-Oléron Bay. Each batch was placed into a small basket in a raceway, in which 20 dying oysters (2 g each) infected by OsHV-1 were also placed, as described in Schikorski, Faury, Pepin, Saulnier, Tourbiez \& Renault (2011). Seawater was heated to $21^{\circ} \mathrm{C}$ and renewed hourly, and all effluents were treated with chlorine. Additionally, oysters were deployed in the field between May and July 2011 at Gresseloup in 171 Bourgneuf Bay $\left(2^{\circ} 7^{\prime} \mathrm{W}, 46^{\circ} 57^{\prime} \mathrm{N}\right)$ and at Agnas $\left(1^{\circ} 10^{\prime} \mathrm{W}, 45^{\circ} 52^{\prime} \mathrm{N}\right)$, La Floride $172\left(1^{\circ} 10^{\prime} \mathrm{W}, 45^{\circ} 48^{\prime} \mathrm{N}\right)$ and La Mortane $\left(1^{\circ} 10^{\prime} \mathrm{W}, 45^{\circ} 53^{\prime} \mathrm{N}\right)$ in Marennes-Oléron Bay, where mortality related to OsHV-1 is typically observed (Table 1). The oysters used at La Mortane and Gresseloup were nursed at the Ifremer nursery in Bouin, while those 
used at the three other sites were nursed at the Ifremer nursery in La Tremblade. The growing methods and the number of oysters tested are indicated in Table 1 , and to summarize, oysters were either tested in intertidal areas (Agnas, La Floride and Gresseloup) or in deeper water where they were always immersed (La Mortane). One bag per batch was deployed at La Mortanne and Gresseloup, while it was two bags of 150 oysters each per batch at Agnas and La Floride. The average individual weight of the oysters at deployment ranged from 0.4 to $2.4 \mathrm{~g}$ (Table 1 ). Mortality was recorded three times per week at the laboratory, and oysters were checked two weeks and one month post-deployment in the field. At Agnas and La Floride, the number of living and dead oysters was recorded one and two months post-deployment. At the endpoint date at all sites, after 4 weeks to 4 months in the field (Table 1), the number of living and dead oysters was determined, and the total weight of the living oysters was also recorded as a measure of the final yield, which was standardized to $1 \mathrm{~kg}$ of spat deployed at the beginning of the experiment.

For experiment 2, the six batches produced were only deployed at Agnas on May $29^{\text {th }}$ 2013 with two bags per batch of 150 oysters each. The average individual weight at deployment was $0.7 \mathrm{~g}$ (Table 1), and survival and yield were both recorded in October 2013.

\section{Determination of DNA ploidy}

DNA ploidy levels were determined by flow cytometry (FCM) using 4',6'-diamidino-2phenylindole (DAPI) staining for the total DNA content of the nucleus. FCM analyses of genome size variation meant that changes in the number or composition of individual 
chromosomes were not measured directly by karyological analyses. Therefore, as suggested by Suda, Krahulcova, Travnicek \& Krahulec (2006), classical cytogenetic terminology (ploidy level) was preceded by the prefix "DNA". At 48 h PF, FCM analysis was used to control initial induction success and to verify the DNA ploidy of the four other batches. Subsequently, FCM was also used to monitor the constitution of triploid-rich batches during larval and spat culture. The DNA ploidy level of larvae from the control and CB-treated groups was determined at each water change for pools of approximately 100 individuals. The DNA ploidy level of the spat was determined using small pieces $\left(1 \mathrm{~mm}^{2}\right)$ of gills collected from juveniles. The samples were first collected in a $1.5 \mathrm{~mL}$ Eppendorf tube containing $1 \mathrm{ml}$ of nuclei extraction buffer ( $5 \mathrm{mM}$ $\mathrm{MgCl}_{2}$, $85 \mathrm{mM} \mathrm{NaCl}, 10 \mathrm{mM}$ Tris, $0.1 \%$ Triton X100, pH 7). Extraction of the nuclei was facilitated by a piston pellet or by syringing the soft tissues with a 26-gauge needle three times. The nuclei were collected by filtration through a $30 \mu \mathrm{m}$ nylon sieve (Celltrics, Partec), mixed with $2 \mu \mathrm{L}$ of trout red blood cells (TRBC, Coulter DNA Reference Calibrator, 629972) as an internal standard solution and stained with DAPI at a concentration of $2 \mu \mathrm{g} \mathrm{mL} \mathrm{m}^{-1}$ in a $2 \mathrm{~mL}$ final solution. FCM was performed on a flow cytometer (PA II, Partec, Sainte Geneviève des Bois, France). The results of the flow cytometric analysis are presented as single-parameter frequency histograms on a 1024 linear scale. Peak positions and CVs were calculated automatically from the Parctec software (PARTEC PAS II, Partec, Sainte Geneviève des Bois, France), and at least 2000 nuclei were analyzed from each sample. The ratio between the respective positions of the sample and TRBC G0/G1 peaks is indicative of the DNA ploidy level of the sample. Under our laboratory conditions, this ratio is 0.4 for diploids and 0.6 for triploids. 


\section{OsHV-1 detection}

224 As any abnormal mortality was noted before testing the batches, and as OsHV-1 had 225 never been detected in any of the animals sampled from our hatchery and nursery prior 226 to their deployment between 2009 and 2011 (Dégremont 2011; Pernet et al. 2012; 227 Dégremont, Guyader, Tourbiez \& Pépin 2013), OsHV-1 detection was performed in 30 and 40 living oysters sampled from all batches in April 2011 and April 2013 for experiments 1 and 2 respectively. Similarly, as OsHV-1 was always found at a very high load in all moribund animals experiencing severe mortality a few weeks postdeployment, six and twelve moribund oysters were sampled during the peak of mortality at each site for experiments 1 and 2 respectively, and screened for OsHV-1 DNA detection and quantification. Briefly, around $50 \mathrm{mg}$ of fresh oyster soft tissue (mantle and gills) was crushed for total DNA extraction using the Qiagen QIAamp ${ }^{\circledR}$ tissue mini kit according to the manufacturer's protocol (QIagen). Final elution of the DNA was performed with $100 \mu \mathrm{l}$ of double-distilled water, and DNA concentration was performed spectrophotometrically (NANODROP®). OsHV-1 detection and quantification used $20 \mathrm{ng}$ of DNA in a final reaction volume of $25 \mu \mathrm{l}$ and was carried out using the $\mathrm{SYBR}^{\circledR}$ Green real-time PCR protocol described by Pépin, Riou \& Renault (2008), which was adapted for primers specific to the OsHV-1 DNA polymerase sequence

(ORF 100), denoted OsHVDPFor: 5'GGTAAATACCATTGGTCTTGTTCC3' (Webb, Fidler \& Renault 2007). The results were expressed as viral DNA copy number per mg of oyster tissue. Specific primers targeting the C2/C6 segment of the OsHV-1 C region ORF4 DNA sequence were used to 
distinguish the $\mu$ Var genotype of OsHV-1 (GenBank \# HQ842610) from the OsHV-1

247 referent (GenBank \# AY509253) (Segarra et al. 2010). The primer sequences used were

CF: 5’CCCCGGGGAAAAAGTATAAA3’

and

CR: 5’GTGATGGCTTTGGTCAAGGT3’ (Pépin J.F., pers. comm.).

\section{Vibrio aestuarianus detection}

252 Due to the observance of higher mortality level in adult C.gigas caused by the Vibrio aestuarianus in France since 2012, the detection of this pathogen was also done for the 12 moribund oysters of experiment 2 using the protocol described in Saulnier, De Decker \& Haffner (2009). The results were expressed as bacteria DNA copy number per mg of oyster tissue.

\section{Statistical analyses}

Statistical analyses were performed on the mortality data and the standardized yield using the SAS ${ }^{\circledR}$ software version 9.3 (SAS Institute Inc., Cary, NC, USA). As the number of oysters per batch at the time of deployment was not a significant factor for experiment 1, it was excluded from all of the subsequent models. The batches $3 \mathrm{nA}$ and $3 n B$ were also removed in order to compare $2 n$ and $3 n$ siblings. Comparison of the cumulative mortality among the batches for both experiments was analyzed using the to the following model: 
Experiment 1: Logit $(Y i j k)=\log (Y i j k /(1-Y i j k))=\mu+$ site $i+$ ploidy $j+$ genotype $k+$ site $i \mathrm{x}$ ploidy $j+$ site $i \mathrm{x}$ genotype $k+$ ploidy $j$ x genotype $k+$ site $i \mathrm{x}$ ploidy $j \mathrm{x}$ genotype $k$

where Yijk is the probability of mortality for an oyster with the $j$ th ploidy (2n, 3n) and the $k$ th genotype (R or $\mathrm{C}$ ) at the ith site (Agnas, La Floride, Laboratory, Gresseloup, La Mortane).

Experiment 2: Logit $(Y i j)=\log (Y i j /(1-Y i j))=\mu+\operatorname{group} i+\operatorname{broodstock} j+\operatorname{group} i \mathrm{x}$ broodstock $j$

where Yij is the probability of mortality for an oyster with the ith group $(2 n C, 2 n R$, 3nR) and the jth broodstock (2 broodstocks used).

Similar models were used for the standardized yield, which was log transformed, through a classic ANOVA using the GLM procedure,

\section{Results}

\section{Ploidy confirmation}

FCM measurement of the DNA ploidy level of larvae analyzed two days PF revealed different profiles. As expected, larvae from the diploid spawn were all diploids, and larvae from the diploid $x$ tetraploid crosses were all triploids. In the CB-treated groups, the populations of two-day-old larvae were mainly triploids (86 to 95\%) with a minor proportion of diploids (5 to $14 \%$ ). For this last group, the majority of fast-growing larvae retained on $85 \mu \mathrm{m}$ mesh screens were triploids, while normal and slow-growing 
larvae, which were not retained on the $85 \mu \mathrm{m}$ mesh screen, were primarily diploids and discarded. At day 15, eyed and pediveliger larvae appeared in the fast-growing, triploidrich fraction of the CB-treated groups. FCM analysis showed that all the progeny sampled after settlement from the diploid $\mathrm{x}$ diploid and diploid $\mathrm{x}$ tetraploid crosses were respectively diploids and triploids. As expected, a very high percentage of triploid oysters was found for the spat analyzed by FCM for the CB-treated groups, with very few (under 2\%) or no diploids.

\section{Mortality}

For experiment 1, mortality was observed five days post-deployment until over two weeks post-deployment in the laboratory trial. Under field conditions, mortality was observed two weeks post-deployment at all sites. Approximately $80 \%$ of the cumulative mortality was observed during the third and fourth weeks post-deployment at Agnas and La Floride, where mortality was recorded within a smaller time frame.

At the endpoint and for experiment 1 , the cumulative mortality within the sites ranged from $63 \%$ in Gresseloup to $72 \%$ in the laboratory. The mean mortality for all of the sites was 33 and $32 \%$ for $2 \mathrm{nR}$ and $3 \mathrm{nR}$, respectively; 91 and $86 \%$ for $2 \mathrm{nC}$ and $3 \mathrm{nC}$, respectively; and 81 and $89 \%$ for $3 n A$ and 3nB, respectively (Table 2). After excluding the $3 \mathrm{nA}$ and $3 \mathrm{nB}$ batches, in order to compare $2 \mathrm{n}$ and $3 \mathrm{n}$ siblings, mortality at the endpoint was 62 and 59\% for diploids and triploids, respectively, and 32 and 88\% for selected and unselected oysters, respectively. All of the effects and their interactions were not significant, with the exception of the genotype effect, for which selected oysters had significantly lower mortality than unselected ones (Table 3). 
312 For experiment 2, the onset of mortality and its duration were the same as in experiment

313 1. Additionally, a similar result was found with a mean mortality of $93 \%$ for 2 nC, $29 \%$ 314 for $2 \mathrm{nR}$ and $21 \%$ for the 3nR in October 2013 (Table 2). A significant interaction was 315 found between the groups and the broodstocks (Table 3). At the broodstock level, 316 mortality was significantly different among the groups $(P<0.0001)$ for both 317 broodstocks, with the highest mortality for the $2 \mathrm{nC}$, and similar mortality between the $318 \quad 2 n R$ and 3nR groups.

\section{Individual weight and standardized yield}

321 The mean individual weight among batches at endpoint per site was ranged from 0.5 to $10.4 \mathrm{~g}$ for experiment 1 , and it was $16.1 \mathrm{~g}$ for experiment 2 (Table 1 ). The standardized yields per $1 \mathrm{~kg}$ of spat deployed are reported in Table 2. The $2 \mathrm{nR}$ and $3 \mathrm{nR}$ batches were

324 found to have the highest yields, which was around 8 to 9-fold higher than the yield for 2nC and 3nC. All the effects and their interactions were not significant, with the exception of the site and genotype for experiment 1 , and the group effect for experiment different (Table 1).

OsHV-1 $\mu$ Var and V. aestuarianus detection

For both experiments, OsHV-1 was not detected in any of the 70 oysters screened prior to deployment. Meanwhile, OsHV-1 was detected for all moribund oysters screened at 
all sites, which represented 30 and 12 animals for experiments 1 and 2 respectively. The viral loads were very high ranging from $10^{+6}$ to $10^{+8}$ DNA copies per mg of fresh tissue. It was also confirmed that the OsHV-1 strain was the $\mu$ Var genotype. No Vibrio aestuarianus were detected in any moribund oysters screened for experiment 2 in 2013.

\section{Discussion}

The ostreid herpesvirus OsHV-1 detected in our study referred to the genotype $\mu$ Var. In the present study, OsHV-1 was not detected before deployment, while all moribund oysters were found positive for OsHV-1, with high viral load $\left(>10^{+6}\right.$ DNA copies per mg of fresh oyster tissue). Such results, as well as the kinetics of the mortality in all sites and the controlled challenge in the laboratory, which mimic mortality pattern in the field, indicate that OsHV-1 could be considered to be the main cause of mortality in $C$. gigas (Pépin et al. 2008; Sauvage, Pépin, Lapègue, Boudry \& Renault 2009; Oden, Martenot, Berthaux, Travaille, Malas \& Houssin 2011; Schikorski et al. 2011). The mortality rates observed in our study according to the size and the genotype are also in agreement with those described in Dégremont (2013) when OsHV-1 is involved (Table 1). Finally, the lack of detection of $V$. aestuarianus during experiment 2 allowed us to exclude this pathogen in the mortality outbreaks observed in our study.

To date, the studies investigating the effect of ploidy on C. gigas mortality have shown all possible results, and no studies have investigated the potential role of the pathogen in the mortality events. For example, Dégremont, Soletchnik \& Boudry (2010b) found similar mortality rates for both ploidy levels, while lower mortality was observed in 
triploids (Gagnaire, Soletchnik, Madec, Gealron, Le Moine \& Renault 2006) and in diploids (Cheney, MacDonald \& Elston 2000). It is important to note that most of the studies on ploidy in C. gigas confounded the ploidy and family effects, more especially when triploids were produced from diploids and tetraploids (i.e. after using genitors with different germplasm and very low effective size), while mortality is a very high heritable trait in juvenile C. gigas (Dégremont et al. 2010a). Thus, the best approach for comparing diploids and triploids is to use genitors sharing the same genetic background. This is possible after chemically inducing triploids from common females and males common founder genotype (indirect method).

The major finding of the present study was that mortality related to OsHV-1 was not affected by ploidy level, which is the first such finding in C. gigas diploids and chemically induced triploids. This is in agreement to the results found for sibling triploid and diploid Sydney rock oysters (Saccostrea glomerata) (Smith, Nell \& Adlard 2000; Hand, Nell \& Thompson 2004; Troup, Cairns \& Simpson 2005). Interestingly, mortality was much lower in both diploids and triploids when parents were selected for higher OsHV-1 resistance (Table 2). Similar results were obtained in an earlier study investigating the effects of ploidy and selective breeding on the summer mortality phenomenon in juvenile $C$. gigas in France: the mortality rates of both diploids and triploids were lower when selected resistant parents were used compared to unselected or susceptible parents (Dégremont et al. 2010b). Similarly, although triploid $C$. virginica exhibited lower mortality than diploids in another study, the findings indicated that mortality due to Haplosporidium nelsoni and Perkinsus marinus decreased as the 
selection progress for disease-resistant strains advanced through both the diploid and tetraploid lines (Dégremont, Garcia, Frank-Lawale \& Allen 2012). Thus, the similar mortality rates in chemically induced triploids and the corresponding diploids suggest that innate resistance to OsHV-1 is not substantially altered by the triploidization strategy and that progress in the selective breeding of diploid oysters for OsHV-1 resistance can be transferred to improve survival in triploids. The present study represents the first report of OsHV-1 resistance in C. gigas triploids. Similar results have previously been reported in fish species for resistance to infectious pancreatic necrosis virus, Vibrio ordalii and Aeromonas salmonicida along with the more recent report of resistance to Flavobacterium psychrophilum in Oncorhynchus mykiss (Dorson, Chevassus \& Torhy 1991; Yamamoto \& Iida 1995; Weber, Wiens, Welch, Hostuttler \& Leeds 2013).

Interactions between ploidy, genotype and environment were not observed, which could easily be explained by the presence of OsHV-1 at all of the sites used in the present study with conditions favoring the disease. In addition, the use of OsHV-1-resistant increase oyster production considerably, especially where OsHV-1 is present.

In the present study, all-triploid batches $3 \mathrm{nA}$ and $3 \mathrm{nB}$ exhibited high mortality rates (81 and $89 \%$, respectively) (Table 2), comparable to that of 2nC (91\%). Similar high mortality associated to OsHV-1 was also reported in commercial triploid oysters in the Thau lagoon and in Australia (Pernet et al. 2012; Jenkins et al. 2013). Even if the use of selected diploid females slightly decreased the mortality rate, as demonstrated by 
405 Dégremont et al. (2010b), the finding underscores the need to develop tetraploid lines 406 from the selected diploid broodstocks available or provide commercial hatcheries the 407 best breeders with the greatest resistance to OsHV-1, as all the triploid oysters are 408 produced in France by mating tetraploid males with diploid females. This approach was 409 recently implemented using both diploid and tetraploid resistant genitor families, and 410 all-triploid resistant oysters have been in production since 2012.

\section{Acknowledgements}

414 We thank the hatchery, nursery and genetic teams of the Laboratory of Genetics and 415 Pathology, IFREMER La Tremblade and IFREMER Bouin for their assistance in oyster 416 production. We greatly acknowledge members of the oyster industry, including Bernard 417 Montauzier and Gérard Billon, for providing study sites and their boats for field 418 operations. 


\section{References}

420

421 Benabdelmouna, A., Ledu, C., 2007. Obtention de mollusques bivalves tetraploïdes à partir de géniteurs diploïdes. Brevet FR2913982A1.

423

Burge C.A. \& Friedman C.S. (2012) Quantifying Ostreid Herpesvirus (OsHV-1) Genome Copies and Expression during Transmission. Microbial Ecology 63, 596604.

Cameron A. \& Crane M. (2011) Final report: OsHV-1 $\mu$ Var International Workshop, Cairns, Queensland, Australia 9-10 July 2011, pp. 101.

Cheney D.P., MacDonald B.F. \& Elston R.A. (2000) Summer mortality of Pacific oysters, Crassostrea gigas (Thunberg): Initial findings on multiple environmental stressors in Puget Sound, Washington, 1998. Journal of Shellfish Research 19, 353-359.

432

Dégremont L. (2011) Evidence of herpesvirus (OsHV-1) resistance in juvenile Crassostrea gigas selected for high resistance to the summer mortality phenomenon. Aquaculture 317, 94-98.

Dégremont L. (2013) Size and genotype affect resistance to mortality caused by OsHV1 in Crassostrea gigas. Aquaculture 416-417, 129-134.

437

Dégremont L., Bédier E. \& Boudry P. (2010a) Summer mortality of hatchery-produced Pacific oyster spat (Crassostrea gigas). II. Response to selection for survival and its influence on growth and yield. Aquaculture 299, 21-29. 
440 Dégremont L., Ernande B., Bedier E. \& Boudry P. (2007) Summer mortality of hatchery-produced Pacific oyster spat (Crassostrea gigas). I. Estimation of genetic parameters for survival and growth. Aquaculture 262, 41-53.

Dégremont L., Garcia C., Frank-Lawale A. \& Allen S.K. (2012) Triploid oysters in the Chesapeake Bay: comparison of diploid and triploid Crassostrea virginica. Journal of Shellfish Research 31, 21-31.

Dégremont L., Guyader T., Tourbiez D. \& Pépin J.-F. (2013) Is horizontal transmission of the Ostreid herpesvirus OsHV-1 in Crassostrea gigas affected by unselected or selected survival status in adults to juveniles? Aquaculture 408-409, 51-57.

Dégremont L., Soletchnik P. \& Boudry P. (2010b) Summer mortality of selected juvenile Pacific oyster Crassostrea gigas under laboratory conditions and in comparison with field performance. Journal of Shellfish Research 29, 847-856.

Dorson M., Chevassus B. \& Torhy C. (1991) Comparative susceptibility of 3 species of char and of rainbow-trout $\mathrm{x}$ char triploid hybrids to several pathogenic salmonid viruses. Diseases of Aquatic Organisms 11, 217-224.

EFSA (2010) Scientific opinion on the increased mortality events in Pacific oysters, Crassostrea gigas. EFSA journal 8, 1-60.

Gagnaire B., Soletchnik P., Madec P., Gealron P., Le Moine O. \& Renault T. (2006) Diploid and triploid Pacific oysters, Crassostrea gigas (Thunberg), reared at two heights above sediment in Marennes-Oleron Basin, France: Difference in mortality, sexual maturation and hemocyte parameters. Aquaculture 254, 606-616.

Garcia C., Thebault A., Dégremont L., Arzul I., Miossec L., Robert M., Chollet B., Francois C., Joly J.-P., Ferrand S., Kerdudou N. \& Renault T. (2011) Ostreid 
herpesvirus 1 detection and relationship with Crassostrea gigas spat mortality in France between 1998 and 2006. Veterinary Research 42,73.

Gérard A., Ledu C., Phelipot P. \& Naciri-Graven Y. (1999) The induction of MI and MII triploids in the Pacific oyster Crassotrea gigas with 6-DMAP or CB. Aquaculture 174, 229-242.

Hand R.E., Nell J.A. \& Thompson P.A. (2004) Studies on triploid oysters in Australia XIII. Performance of diploid and triploid Sydney rock oyster, Saccostrea glomerata (Gould, 1850), progeny from a third generation breeding line. Aquaculture 233, 93-107.

Jenkins C., Hick P., Gabor M., Spiers Z., Fell S.A., Gu X.N., Read A., Go J., Dove M., O'Connor W., Kirkland P.D. \& Frances J. (2013) Identification and characterisation of an ostreid herpesvirus-1 microvariant (OsHV-1 mu-var) in Crassostrea gigas (Pacific oysters) in Australia. Diseases of Aquatic Organisms 105, 109-126.

Le Deuff R.M., Nicolas J.L., Renault T. \& Cochennec N. (1994) Experimental transmission of a Herpes-like virus to axenic larvae of Pacific oyster, Crassostrea gigas. Bulletin of The European Association Of Fish Pathologists 14, 69-72.

Lynch S.A., Carlsson J., Reilly A.O., Cotter E. \& Culloty S.C. (2012) A previously undescribed ostreid herpes virus $1(\mathrm{OsHV}-1)$ genotype detected in the pacific oyster, Crassostrea gigas, in Ireland. Parasitology 139, 1526-1532.

Martenot C., Fourour S., Oden E., Jouaux A., Travaille E., Malas J.P. \& Houssin M. (2012) Detection of the OsHV-1 mu Var in the Pacific oyster Crassostrea gigas before 2008 in France and description of two new microvariants of the Ostreid Herpesvirus 1 (OsHV-1). Aquaculture 338, 293-296. 
Oden E., Martenot C., Berthaux M., Travaille E., Malas J.P. \& Houssin M. (2011) Quantification of ostreid herpesvirus 1 (OsHV-1) in Crassostrea gigas by realtime PCR: Determination of a viral load threshold to prevent summer mortalities. Aquaculture 317, 27-31.

Paul-Pont I., Dhand N.K. \& Whittington R.J. (2013) Influence of husbandry practices on OsHV-1 associated mortality of Pacific oysters Crassostrea gigas. Aquaculture 412-413, 202-214.

Peeler E.J., Allan Reese R., Cheslett D.L., Geoghegan F., Power A. \& Thrush M.A. (2012) Investigation of mortality in Pacific oysters associated with Ostreid herpesvirus-1 $\mu$ Var in the Republic of Ireland in 2009. Preventive Veterinary Medicine 105, 136-143.

Pépin J.F., Riou A. \& Renault T. (2008) Rapid and sensitive detection of ostreid herpesvirus 1 in oyster samples by real-time PCR. Journal of Virological Methods 149, 269-276.

Pernet F., Barret J., Le Gall P., Corporeau C., Dégremont L., Lagarde F., Pépin J.F. \& Keck N. (2012) Mass mortalities of Pacific oysters Crassostrea gigas reflect infectious diseases and vary with farming practices in the Mediterranean Thau lagoon, France. Aquaculture Environment Interactions 2, 215-237.

Roque A., Carrasco N., Andree K.B., Lacuesta B., Elandaloussi L., Gairin I., Rodgers C.J. \& Furones M.D. (2012) First report of OsHV-1 microvar in Pacific oyster (Crassostrea gigas) cultured in Spain. Aquaculture 324, 303-306.

Samain J-F. \& McCombie H. (2008) Summer mortality of Pacific oysters Crassostrea gigas. The MOREST Project, Quae Editions, Versailles. 
510 Saulnier D., De Decker S. \& Haffner P. (2009) Real-time PCR assay for rapid detection and quantification of Vibrio aestuarianus in oyster and seawater: A useful tool for epidemiologic studies. Journal of Microbiological Methods 77, 191-197.

Sauvage C., Pépin J.F., Lapègue S., Boudry P. \& Renault T. (2009) Ostreid herpes virus 1 infection in families of the Pacific oyster, Crassostrea gigas, during a summer mortality outbreak: Differences in viral DNA detection and quantification using real-time PCR. Virus Research 142, 181-187.

Schikorski D., Faury N., Pepin J.F., Saulnier D., Tourbiez D. \& Renault T. (2011) Experimental ostreid herpesvirus 1 infection of the Pacific oyster Crassostrea gigas: Kinetics of virus DNA detection by q-PCR in seawater and in oyster samples. Virus Research 155, 28-34.

Segarra A., Pépin J.F., Arzul I., Morga B., Faury N. \& Renault T. (2010) Detection and description of a particular Ostreid herpesvirus 1 genotype associated with massive mortality outbreaks of Pacific oysters, Crassostrea gigas, in France in 2008. Virus Research 153, 92-99.

Smith I.R., Nell J.A. \& Adlard R. (2000) The effect of growing level and growing method on winter mortality, Mikrocytos roughleyi, in diploid and triploid Sydney rock oysters, Saccostrea glomerata. Aquaculture 185, 197-205.

Suda J., Krahulcova A., Travnicek P. \& Krahulec F. (2006) Ploidy level versus DNA ploidy level: an appeal for consistent terminology. Taxon 55, 447-450.

Troup A.J., Cairns S.C. \& Simpson R.D. (2005) Growth and mortality of sibling triploid and diploid Sydney rock oysters, Saccostrea glomerata (Gould), in the Camden Haven River. Aquaculture Research 36, 1093-1103. 
533 Webb S.C., Fidler A. \& Renault T. (2007) Primers for PCR-based detection of ostreid herpes virus-1 (OsHV-1): Application in a survey of New Zealand molluscs. Aquaculture 272, 126-139.

Weber G.M., Wiens G.D., Welch T.J., Hostuttler M.A. \& Leeds T.D. (2013)

537 Comparison of disease resistance between diploid, induced-triploid, and intercross-triploid rainbow trout including trout selected for resistance to Flavobacterium psychrophilum. Aquaculture 410-411, 66-71.

540 Yamamoto A. \& Iida T. (1995) Susceptibility of triploid rainbow-trout to IHN, furunculosis and vibriosis. Fish Pathology 30, 69-70.

542 
Figure 1 Crosses within or between broodstocks for the production of the six batches for experiment 1 . The location of the starting point of a given arrow between two sexes indicates which parents were used.

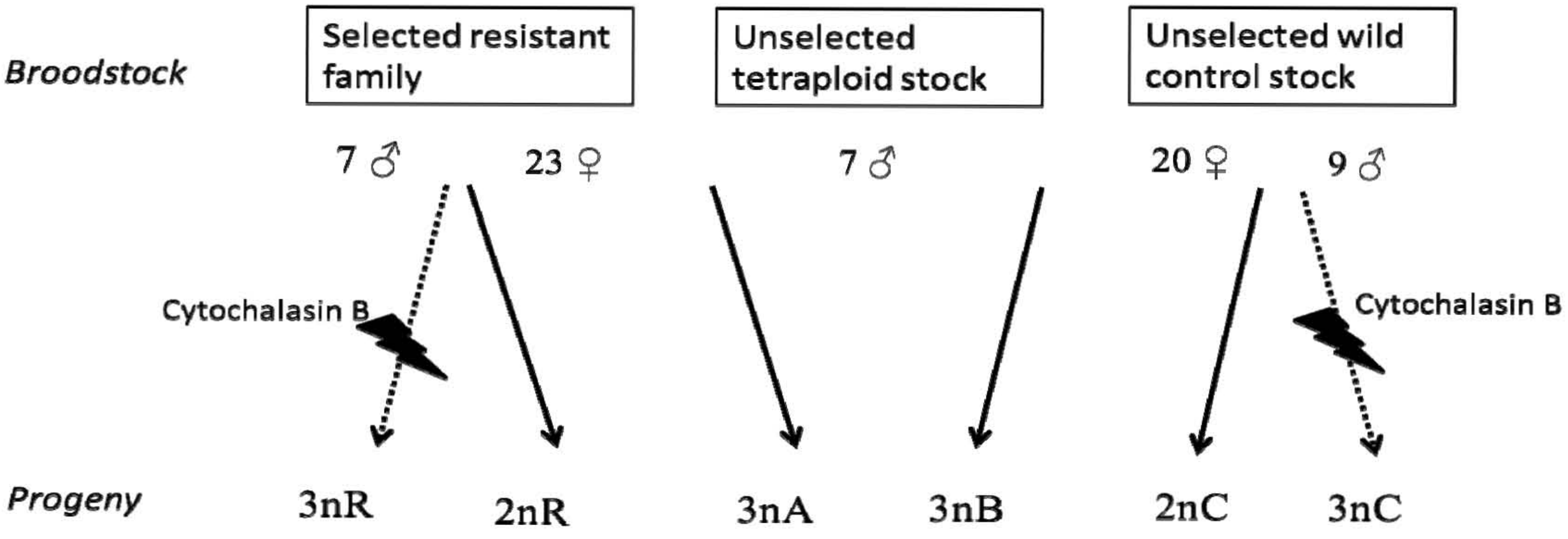


1 Table 1 Summary of the key dates, growing methods, and number of oysters tested at each site for both experiments

\begin{tabular}{|c|c|c|c|c|c|c|c|}
\hline Experiment & Site & $\begin{array}{c}\text { Date of } \\
\text { deployment }\end{array}$ & $\begin{array}{c}\text { Date of } \\
\text { endpoint }\end{array}$ & $\begin{array}{l}\text { Growing } \\
\text { method }\end{array}$ & $\begin{array}{c}\text { Number of } \\
\text { oysters per } \\
\text { batch }\end{array}$ & $\begin{array}{c}\text { Individual } \\
\text { weight at } \\
\text { deployment } \\
\text { (g)* }\end{array}$ & $\begin{array}{c}\text { Individual } \\
\text { weight at } \\
\text { endpoint (g) }\end{array}$ \\
\hline $\bar{A}$ & Laboratory & $04 / 26 / 11$ & $05 / 13 / 11$ & $\begin{array}{c}\text { Raceway and } \\
\text { cylindrical } \\
\text { basket }\end{array}$ & 50 & $0.4 \pm 0.1$ & $0.5 \pm 0.1$ \\
\hline A & Agnas & 05/03/11 & 09/20/11 & $\begin{array}{c}\text { Rebar racks } \\
\text { and plastic bag }\end{array}$ & 300 & $0.5 \pm 0.1$ & $10.4 \pm 3.1$ \\
\hline A & La Floride & $05 / 04 / 11$ & 09/20/11 & $\begin{array}{c}\text { Rebar racks } \\
\text { and plastic bag }\end{array}$ & 300 & $0.4 \pm 0.1$ & $8.4 \pm 2.0$ \\
\hline A & Gresseloup & $06 / 01 / 11$ & 07/06/11 & $\begin{array}{c}\text { Rebar racks } \\
\text { and plastic bag }\end{array}$ & 500 & $0.6 \pm 0.1$ & $1.6 \pm 0.3$ \\
\hline A & La Mortane & 07/08/11 & $08 / 23 / 11$ & $\begin{array}{l}\text { Sea cages and } \\
\text { plastic bag }\end{array}$ & 500 & $2.4 \pm 0.3$ & $7.5 \pm 2.2$ \\
\hline B & Agnas & $06 / 25 / 13$ & $10 / 8 / 13$ & $\begin{array}{c}\text { Rebar racks } \\
\text { and plastic bag }\end{array}$ & 300 & $0.7 \pm 0.1$ & $16.1 \pm 3.6$ \\
\hline
\end{tabular}

Mean \pm standard deviation among batches. 
4 Table 2 Mean cumulative mortality (\%) and standardized yield (kg) among sites for selected (R) and unselected (C) diploid (2n) and 5 triploid (3n) C. gigas and all-triploid C. gigas (3nA and 3nB) for both experiments

\begin{tabular}{|c|c|c|c|c|c|}
\hline & & \multicolumn{2}{|c|}{ Mortality } & \multicolumn{2}{|c|}{ Standardized yield } \\
\hline \multicolumn{2}{|c|}{ Experiment } & $2 n$ & $3 n$ & $2 n$ & $3 n$ \\
\hline \multirow[t]{4}{*}{$A^{*}$} & $\mathrm{R}$ & $32.6 \pm 7.1$ & $31.7 \pm 6.7$ & $9.2 \pm 8.1$ & $9.7 \pm 8.2$ \\
\hline & $\mathrm{C}$ & $90.5 \pm 3.4$ & $85.3 \pm 8.3$ & $0.9 \pm 0.8$ & $1.4 \pm 0.9$ \\
\hline & $3 n A$ & & $81.4 \pm 3.5$ & & $3.1 \pm 2.8$ \\
\hline & $3 n B$ & & $88.9 \pm 2.5$ & & $1.4 \pm 1.2$ \\
\hline \multirow[t]{2}{*}{$\mathrm{B}+$} & $\mathrm{R}$ & $29.5 \pm 12.0$ & $21.3 \pm 14.1$ & $12.9 \pm 1.7$ & $14.0 \pm 4.3$ \\
\hline & $\mathrm{C}$ & $93.0 \pm 1.4$ & & $1.8 \pm 1.1$ & \\
\hline
\end{tabular}

* Mean \pm standard deviation among sites

7 † Mean \pm standard deviation among broodstocks 
Table 3 Logit analysis of the cumulative mortality for experiment A in 2011 and experiment B in 2013

\begin{tabular}{|c|c|c|c|c|}
\hline Experiment & Source & $\mathrm{df}$ & $\chi^{2}$ & $P$ \\
\hline \multirow[t]{7}{*}{$A$} & site & 4 & 5.71 & 0.22 \\
\hline & genotype & 1 & 117.11 & $<0.0001$ \\
\hline & ploidy & 1 & 0.31 & 0.58 \\
\hline & site $\mathrm{x}$ ploidy & 4 & 0.83 & 0.93 \\
\hline & site $\mathrm{x}$ genotype & 4 & 4.54 & 0.34 \\
\hline & ploidy x genotype & 1 & 0.21 & 0.64 \\
\hline & $\begin{array}{l}\text { site x ploidy x } \\
\text { genotype }\end{array}$ & 4 & 1.98 & 0.74 \\
\hline \multirow[t]{3}{*}{ B } & group & 2 & 146.38 & $<0.0001$ \\
\hline & broodstock & 1 & 0.01 & 0.92 \\
\hline & group $\mathrm{x}$ broodstock & 2 & 10.14 & 0.0066 \\
\hline
\end{tabular}


Table 4 Anova of the standardized yield for experiment A in 2011 and experiment B in 2013

\begin{tabular}{|c|c|c|c|c|}
\hline Experiment & Source & $\mathrm{df}$ & $\mathrm{F}$ & $P$ \\
\hline \multirow[t]{8}{*}{$\mathrm{A}$} & site & 4 & 111.25 & $<0.0001$ \\
\hline & genotype & 1 & 197.77 & $<0.0001$ \\
\hline & ploidy & 1 & 1.16 & 0.31 \\
\hline & site $\mathrm{x}$ ploidy & 4 & 0.84 & 0.54 \\
\hline & site $\mathrm{x}$ genotype & 4 & 2.76 & 0.10 \\
\hline & ploidy x genotype & 1 & 0.22 & 0.66 \\
\hline & $\begin{array}{l}\text { site } \mathrm{x} \text { ploidy } \mathrm{x} \\
\text { genotype }\end{array}$ & 4 & 1.78 & 0.23 \\
\hline & error & 8 & & \\
\hline \multirow[t]{4}{*}{ B } & group & 2 & 31.86 & 0.0006 \\
\hline & broodstock & 1 & 0.43 & 0.53 \\
\hline & group x broodstock & 2 & 3.18 & 0.11 \\
\hline & error & 6 & & \\
\hline
\end{tabular}

